\title{
Gamification for Increasing Learning Motivation of College Student
}

\author{
Agnes Kurniati ${ }^{1 *}$, Francisco Maruli Panggabean ${ }^{2}$, Nadia $^{3}$, Thomas Galih Satria ${ }^{4}$ \\ ${ }^{1,2,3,4}$ Computer Science Department, School of Computer Science \\ Bina Nusantara University, \\ Jakarta, Indonesia 11480 \\ akurniati@binus.edu; fpanggabean@binus.edu; nadia@binus.edu; tsatria@binus.edu \\ *Correspondence: akurniati@binus.edu
}

\begin{abstract}
The purpose of this research is to build an attractive gamification system that could motivate college students as the user target by customized challenges with adjustable difficulty-scaled reward systems. The methods used for the research consists of problem identification, collecting and analyzing the data, problem formulation, solution and design creation, product implementation, and evaluation. StudyGO is a mobile application that has 2 main features that have gamification aspects which are focused and scheduled study. The application evaluation is done with questionnaire evaluation based on 5 measurable human factors. The majority results from the application feels very motivated and rewarded enough from this gamification system.
\end{abstract}

Keywords: Gamification, Motivation, Mobile Application

\section{INTRODUCTION}

People nowadays have very diverse needs, ranging from shopping, transportation, education, and so on, where these needs are very important for the survival of modern times. One way to meet these needs is through applications found on smartphones or smart phones which are now very easily accessed by various groups of people. There are so many applications that are circulating for smartphones. In the first quarter of 2020, 2.56 million applications were available through the Google Play Store, which was the main application store for the Android platform, while 1.84 million applications were available through the Apple App Store which was the main application store for the iOS platform in the first quarter of 2020 , and this number still growing.
Smartphones are now very common in various levels of society in Indonesia. Indonesia has a population of 272.1 million people at the beginning of 2020 , where $94 \%$ of the active population have smartphones as a means of communication compared to laptops or personal computers / PCs which are only owned by $66 \%$ of Indonesia's active population (We Are Social, 2020).

Smartphones are preferred by Indonesians to personal computers (PCs) or laptops because smartphones make it easy to communicate and access various content and materials via the internet at very affordable costs for Indonesians (Puspitasari \& Ishii, 2016).

Smartphones circulating in Indonesia are currently dominated by the Android OS / operating system. Google's Android operating system users in Indonesia have reached $92.64 \%$ of all smartphones owned by Indonesians, and the rest are controlled by iOS from Apple and other OS (Global Stats, 2020).

The large amount of use of the Android OS is due to several reasons, starting from the user interface and user experience which is very easy to customize to make smartphone use easier, a more stable OS system to run various applications on various devices compared to iOS, and is available in various types and brands of smartphones at affordable prices. specifications can adjust the needs of its users (Lazareska, 2017).

The applications circulating in the application store for both Android (Google Play Store) and iOS (Apple App Store) have various application categories that can be downloaded by users as needed. Application categories which can be such as games/games, utilities, communication/ social media, productivity, mobility, entertainment, photography, health, books, device personalization, education, and finance are application categories that are 
often downloaded and used through the Android and iOS platforms to fulfill daily needs of the community.

Gamification is the use of game elements such as game mechanics, game aesthetics, and game thinking to invite people to participate, motivate, and solve and solve problems in a non-game / non-game context. Gamification has a reward system as a form of reward for gamification participants for solving a problem. This reward system often has no relationship with the problems at hand, but it can be a benchmark for participants to measure the things that participants have done. Gamification can also help participants not feel afraid of failure, this is because most games help participants see that failure is not the end of everything, so participants are motivated to experiment, practice, and learn new things from their previous failures. (Buckley \& Doyle, 2016)

Gamification has many types of applications, starting from gamification of education, productivity, business / finance, health, and other non-gaming contexts. In educational gamification, gamification applications such as Kahoot and Classcraft are very often used to increase teacher interaction with students, create opportunities and challenges to gain knowledge, increase group cohesiveness, and increase learning motivation which is the main goal of educational gamification. (Bicen \& Kocakoyun, 2017) Based on research data from Bicen which of 65 students as respondents, $82 \%$ of respondents answered that gamification can motivate to study harder with value competition, $71 \%$ of respondents also said they were motivated to achieve higher grades. high, 94\% of respondents answered that gamification helps / facilitates their learning. (Bicen \& Kocakoyun, 2018)

Motivation itself means being moved to do something with inspiration or encouragement from various things from within and without. Two types of motivation based on what drives the motivation of each individual are called intrinsic motivation and extrinsic motivation, respectively. Intrinsic motivation or self-motivation arises because a job that is done feels interesting, enjoyable, and challenges oneself without any outside influence. Intrinsic motivation appears with human nature who likes to play, has a sense of curiosity, and is ready to learn new things, so that this activity becomes an attraction and a reward for the psychological needs of the participants such as competence and so on. (Ryan \& Deci, 2000; see also Buckley \& Doyle, 2016)

Extrinsic motivation begins to emerge when intrinsic motivation meets social demands (whether school, family, environment, etc.) which reduces the sense of intrinsic motivation. Extrinsic motivation occurs when an individual performs an activity to get the desired result and avoids punishment if he fails to carry out the activity. Motivation can also be triggered from the rewards you get. There are those who have a character based on seeing the prizes they will get, others think that the prizes they receive are not so relevant so that participants continue to do so with other motivations. This can be seen if participants do their job poorly by looking at the prizes they get, in the future they are most likely to not do tasks that have no prizes at all
(Buckley \& Doyle, 2016; Nicholson, 2015; Vella et al., 2017).

With 2 motivational characteristics that can affect the learning process, students need a variety of stimuli and a supportive learning environment. Coupled with different motivations, each student needs a different stimulus. Demotivation that occurs in the student environment can reduce motivation and achievement both within the scope of the school (assessment system, teaching quality, teacher / lecturer behavior towards students / students, time) and family (value / future demands). This stimulus is needed to reduce the demotivating factors mentioned. With gamification as a stimulus, it is hoped that student motivation and learning achievement will increase (Buckley \& Doyle, 2016; Johnson et al., 2016; Khusyabaroh et al., 2018).

Based on research data from Santoso and Siang on students, problems that are often found in students are about inhibiting motivation on a scale of 1-4 (scale 4: The most important factor, 1: the lowest factor) in learning such as feeling wrong majoring inappropriate, difficult to absorb material, activities outside campus, personal / family problems, and so on (Hasibuan, 2019). These factors can cause learning stress, and this can reduce motivation to learn. In a study conducted by Hasibuan, students with low and moderate stress levels ( 73 out of 76 respondents) experienced a decrease in learning motivation from high motivation to moderate motivation (42 out of 76 respondents). A decrease in learning motivation will have an impact on decreased learning achievement as well (Santoso \& Siang, 2016).

All of the motivational factors mentioned earlier regarding the inhibiting effect of motivation can be related to the motivational components studied by Saija through his research, namely 'Undergraduate Student's Motivation and Self-Regulated Learning in Learning Statistics: Female vs Male" where these components consist of self efficacy (SE) or an individual's self-confidence in his or her own ability to solve a problem, then there is test anxiety (TA), where anxiety about failure before facing a test or challenge. In addition, there are intrinsic value (IV) which determines whether something faced has an important meaning or value, self-regulation (SR) or self-regulation is the process of regulating behavior and emotions in the learning process, and cognitive strategy use (CSU) to regulate effective way of learning. In the research related to these motivational factors, with indicators ranging in value from 4.6 to 5.8 on all motivational factors, namely SE / self-efficacy, IV / intrinsic value, TA / test anxiety, and CSU / cognitive strategy use shows that motivational students can encourage learning activities to achieve better academic results (Saija, 2019)

Based on this problem, it can be formulated to this research questions; 1) How to increase student motivation to learn? 2) How to attract students to learn? 


\section{METHODS}

In this study, we need a gamification system to determine how to increase student learning motivation. We need a sample of data that can represent college student motivation in learning. The data sample was collected using a questionnaire with a simple random sampling method which was distributed through social media. After the data is obtained, proceed with making applications based on the collected data. The application is then tested by the user. The application will be evaluated by the user using a Likert scale. The evaluation results will show whether the application with gamification can increase student learning motivation.

To determine the gamification feature that will be implemented into the application, data collection was carried out using the simple random sampling method for students. Of the 50 respondents who filled out the questionnaire, the following conclusions were obtained:

1. As many as $64 \%$ of respondents prefer to study alone rather than study in groups $(36 \%)$

2. The learning process is carried out once a week $(30 \%)$ and before the exam $(40 \%)$

3. The average duration of study was 2 hours and 46 minutes

4. As many as $70 \%$ of respondents learn because of external factors (exams, tests) and 30\% study because of curiosity

5. There are distractions faced during learning activities, namely the desire to play video games, look at social media, and lack confidence.

6. After studying, respondents reward themselves by buying things they like, doing hobbies, taking breaks, and seeing learning as a valuable experience.

In addition to questionnaires, applications are made by making comparisons with similar applications. Based on similar applications, there are several features that will be implemented:

1. Focused study mode

Users can choose activities / learning methods with adjustable difficulty levels. Completing this mode will get the currency

2. Set a daily schedule

Users can create study schedules

3. Game mode

This mode is made for the user to rest. This mode can be played using the currency you have

4. Achievement

Prizes for achievements that are owned by users in the form of medals, trophies or titles

5. Avatar customization

Players can customize the avatar that will be displayed on the profile $\&$ message board

6. Profile \& message board
Feature to display avatars and messages to other users

7. Social

This feature is used to connect application users using social media integration

8. Exchange shop

This feature is used to exchange currency for cosmetics, avatars, collectibles, and mini games that can be played in game mode

\section{RESULTS AND DISCUSSION}

This research produces a product in the form of an application namely StudyGO. This application is made based on the results of a questionnaire and analysis of similar applications. This application combines learning and game elements. Every time a user completes a lesson, the user gets a currency that can be used to play games.

To answer research questions, this application must be tested first. Application testing is done by collecting data using a questionnaire with a random sampling method. The contents of the questionnaire are in the form of evaluation of the usefulness of applications and the effect of increasing student learning motivation. This questionnaire is distributed to students. The results of the questionnaire can be seen in Table 1 and Table 2 .

Table 1 Questionnaire Result 1

\begin{tabular}{rlcc}
\hline No & \multicolumn{1}{c}{ Statement } & Agree & Disagree \\
\hline S.1.1 & $\begin{array}{l}\text { StudyGO apps is } \\
\text { rewarding }\end{array}$ & 35 & 15 \\
\hline S.1.2 & $\begin{array}{l}\text { StudyGO apps is fun } \\
\text { to use }\end{array}$ & 39 & 11 \\
\hline S.1.3 & $\begin{array}{l}\text { StudyGO application } \\
\text { helps users to learn }\end{array}$ & 42 & 8 \\
\hline
\end{tabular}

Table 2 Questionnaire Result 2

\begin{tabular}{|c|c|c|c|c|c|c|}
\hline No & Statement & 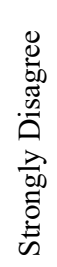 & 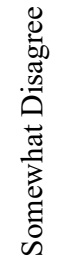 & 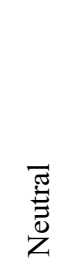 & 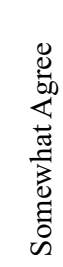 & 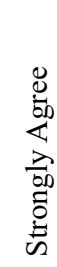 \\
\hline S.2.1 & $\begin{array}{l}\text { Reward given by } \\
\text { apps is satisfying }\end{array}$ & 3 & 4 & 16 & 18 & 9 \\
\hline S.2.2 & $\begin{array}{l}\text { StudyGO apps is } \\
\text { easy to use }\end{array}$ & 1 & 6 & 7 & 22 & 14 \\
\hline S.2.3 & $\begin{array}{l}\text { UI of the apps is } \\
\text { easy to understand }\end{array}$ & 2 & 4 & 13 & 20 & 11 \\
\hline S.2.4 & $\begin{array}{l}\text { Features in } \\
\text { StudyGO apps is } \\
\text { easy to understand }\end{array}$ & 1 & 4 & 12 & 18 & 15 \\
\hline S.2.5 & $\begin{array}{l}\text { The UI makes it } \\
\text { easy for users to use } \\
\text { apps }\end{array}$ & 1 & 2 & 7 & 27 & 13 \\
\hline
\end{tabular}


Based on the results of the questionnaire in Table 1 and Table 2, the average value for each setting is obtained, which can be seen in Table 3 .

\begin{tabular}{|c|c|}
\hline Statement & Mean \\
\hline S.1.1 & 0,7 \\
\hline S.1.2 & 0,78 \\
\hline S.1.3 & 0,84 \\
\hline S.2.1 & 0,704 \\
\hline S.2.2 & 0,768 \\
\hline S.2.3 & 0,736 \\
\hline S.2.4 & 0,768 \\
\hline S.2.5 & 0,796 \\
\hline
\end{tabular}

\section{CONCLUSION}

Based on this research, we found that student motivation to learn was increased by the existence of a satisfactory reward system (S.1.1 with a mean of 0.7 and S.2.1 with a mean of 0.704) and a fun application (S.1.2 with a mean of 0.78 ), so that as a whole, the application helps students to learn (S.1.3 with mean 0.84). Students are also interested in learning using the gamification system because the application is easy to use (S.2.2 with mean 0.768), features on apps are easy to understand (S.2.4 with mean 0.768), and UI on apps is easy to understand and makes it easier for users to use apps (S.2.3 with a mean 0.736 and S.2.5 with a mean 0.796 )

\section{REFERENCES}

Buckley, P., \& Doyle, E. (2016). Gamification and student motivation. Interactive Learning Environments, 24(6), 1162-1175. https://doi.org/10.1080/10494 820.2014 .964263

Global Stats. (2020). Mobile Operating System Market Share Indonesia. https://gs.statcounter.com/osmarket-share/mobile/indonesia

Hasibuan, M. T. D. (2019). Hubungan Stres Belajar Dengan Motivasi Belajar Pada Mahasiswa Yang Menjalani Pendidikan Di Sekolah Tinggi Ilmu Kesehatan Murni Teguh. Indonesian Trust Health Journal, 2(1), 128-131. https://doi.org/10.37104/ithj. v2i1.24

Johnson, M. L., Taasoobshirazi, G., Clark, L., Howell, L., \& Breen, M. (2016). Motivations of Traditional and Nontraditional College Students: From Self-Determination and Attributions, to Expectancy and Values. Journal of Continuing Higher Education, 64(1), 3-15. https://doi.org/10.1080/07377 363.2016 .1132880

Khusyabaroh, L., Widiati, U., \& Anugerahwati, M. (2018). Demotivating factors in learning English for elementary school students. Jurnal Pendidikan Humaniora, 6(3), 134-144. http://www.kapee.or.kr/ data/board/b21_62.pdf

Lazareska, L. (2017). Analysis of the Advantages and Disadvantages of Android and iOS Systems and Converting Applications from Android to iOS Platform and Vice Versa. American Journal of Software Engineering and Applications, 6(5), 116. https://doi.org/10.11648/j.ajsea.20170605.11

Nicholson, S. (2015). A Recipe for Meaningful Gamification. Gamification in Education and Business. https://doi.org/10.1007/978-3-319-10208-5

Puspitasari, L., \& Ishii, K. (2016). Digital divides and mobile Internet in Indonesia: Impact of smartphones. Telematics and Informatics, 33(2), 472483. https://doi.org/10.1016/j.tele.2015.11.001

Saija, L. M. (2019). Undergraduate students' motivation and self-regulated learning in learning statistics: Female vs male. Journal of Physics: Conference Series, 1320(1). https://doi.org/10.1088/1742$6596 / 1320 / 1 / 012104$

Santoso, H. B., \& Siang, J. J. (2016). Faktor - faktor penentu motivasi dan demotivasi mahasiswa sistem informasi (studi kasus: universitas kristen duta wacana) 1. Seminar Nasional Sistem Informasi Indonesia, $i$ (November), 155-162.

Vella, K., Cheng, V. W. S., Johnson, D., Davenport, T., Peever, N., \& Mitchell, J. (2017). Motivating engagement with a wellbeing app using video games and gamification. CEUR Workshop Proceedings, 2055.

We Are Social. (2020). DIGITAL AROUND THE WORLD IN APRIL 2020. DIGITAL 2020. https:// wearesocial.com/blog/2020/04/digital-aroundthe-world-in-april-2020 